\title{
ANALISIS PERBANDINGAN PERTUMBUHAN POPULASI KERANG LUMPUR (Anodontia edentula, Linnaeus 1758) DI PERAIRAN KEPULAUAN TOBEA DAN LAMBIKU, KECAMATAN NAPABALANO, KABUPATEN MUNA
}

\author{
Rochmady* Sharifuddin Bin Andy Omar** Lodewyck S. Tandipayuk** \\ * Staf Pengajar Jurusan Budidaya Perairan Sekolah Tinggi Pertanian Wuna- Raha \\ ** Staf Pengajar PASCASARJANA FIKP UNHAS-Makassar
}

\begin{abstract}
ABSTRAK
Penelitian dilakukan di Kepulauan Tobea dan Lambiku untuk menganalisis: perbedaan pertumbuhan populasi kerang lumpur Anodontia edentula Linnaeus, 1758 di kedua daerah. Data dianalisis untuk melihat pertumbuhan populasi di kedua lokasi dengan menggunakan analisis pertumbuhan von Bertanlanfy.

Hasil analisis menunjukkan pertumbuhan kerang lumpur Anodontia edentula Linnaeus, 1758 di Kepulauan Tobea, $\left(L_{\infty}=65,6 \mathrm{~mm}, K=1,18\right)$ lebih kecil dibandingkan di Lambiku $\left(L_{\infty}=73,75 \mathrm{~mm}, K=0,73\right)$. Perbedaan pertumbuhan populasi lebih diakibatkan karena perbedaan karakteristik lokasi. Pada daerah Kepulauan Tobea memiliki pertumbuhan lambat karena pengaruh laut lebih dominan dibanding pada daerah Lambiku yang lebih banyak mendapatkan pengaruh daratan.
\end{abstract}

\section{Kata Kunci: Pertumbuhan, Kerang Lumpur Anodontia edentula.}

\section{PENDAHULUAN}

\subsection{Latar Belakang}

Pesisir Bonea dan Lambiku merupakan dua daerah di Kecamatan Napabalano, dengan potensi kerang lumpur A. edentula (Poutries, 1998; Carpenter dan Niem, 1998; Cosel, 2006). Daerah Bonea, aktivitas pengambilan kerang lumpur telah berlangsung lama, dan daerah Lambiku merupakan lokasi pengambilan kerang lumpur yang tergolong baru. Kedua lokasi ini memiliki karakteristik lingkungan ekosistem mangrove yang berbeda. Selain itu, terdapat pula lokasi pengambilan kerang lumpur yakni pada daerah kepulauan Tobea.

Pemanfaatan tak terkendali oleh masyarakat lokal terhadap individu kerang dan perubahan struktur ekosistem mangrove yang telah lama mengkonsumsi kerang lumpur ini dikhawatirkan dapat mengakibatkan penurunan besar populasi dan tingkat keragaman, bahkan dapat berdampak terhadap kepunahan. Selain itu, perubahan ekosistem pada daerah Kepulauan Tobea dan Lambiku sebagai akibat dari konversi hutan mangrove menjadi tambak rakyat, pemanfaatan hasil hutan mangrove sebagai kayu bakar, pencemaran akibat sampah domestik, penggunaan racun maupun sebab-sebab lain, dapat menyebabkan terjadinya kerusakan dan penurunan kualitas lingkungan yang merupakan habitat berbagai organisme laut, termasuk moluska.

Oleh karena permintaan yang cenderung tinggi, mengakibatkan eksploitasi terhadap spesies kerang cenderung tinggi pula. Akibat dari tekanan eksploitasi yang tinggi dapat mengakibatkan terjadinya penurunan populasi. Berdasarkan hasil wawancara dengan nelayan pengambil kerang lumpur diperoleh informasi bahwa jumlah tangkapan yang diperoleh relatif mengalami penurunan. Selain itu, ukuran yang diperoleh relatif lebih kecil dari ukuran pada pengambilan tahun-tahun sebelumnya. Jika hal ini berlangsung secara kontinu dalam kurun waktu tertentu, kekhawatiran akan kepunahan dapat saja terjadi. Sebagai akibat dari beberapa faktor di atas, jumlah dan ukuran maksimum kerang lumpur yang diperoleh mengalami penurunan.

Minimnya bahkan hampir tidak adanya data dan informasi tentang kerang lumpur ini sangat disayangkan. Oleh karena itu, merupakan suatu hal yang penting untuk mengungkap 
informasi pertumbuhan populasi kerang lumpur. Penelitian ini merupakan suatu upaya untuk menduga aspek pertumbuhan populasi dari kerang lumpur $A$. edentula yang berada di Kepulauan Tobea dan Lambiku, pesisir Kabupaten Muna. Hasil penelitian ini diharapkan dapat digunakan sebagai informasi dan bahan kajian pengelolaan kerang tersebut di Kabupaten Muna khususnya dan Indonesia pada umumnya. Informasi yang diperoleh diharapkan dapat memberikan nilai tambah terhadap informasi kekerangan di Indonesia.

Bivalvia (oysters, scallops, clams, cachles dan mussels) bahkan hampir semua spesies dari Bivalvia dapat dimanfaatkan untuk berbagai kebutuhan manusia, meskipun hanya beberapa jenis bernilai ekonomis penting (Taylor dan Glover 2000, 2004 dan 2007). Bivalvia bernilai ekonomis penting di antaranya adalah tiram yang menghasilkan mutiara dan sebagai sumber protein hewani yang penting, terutama bagi penduduk yang mendiami daerah pesisir.

Lebata (2000 dan 2001) melaporkan tentang pengambilan oksigen, sulfida dan nutrien A. edentula pada daerah mangrove berlumpur, menunjukkan bahwa konsentrasi sulfida yang berkurang secara drastis dibandingkan dengan percobaan yang tidak menggunakan kerang tersebut. Spesies A. edentula dapat meningkatkan kadar estradiol dalam darah manusia yang mengkonsumsi. Sjafaraenan (2011), melaporkan bahwa konsentrasi estradiol dalam darah mengalami peningkatan yang signifikan terhadap wanita yang mengkonsumsi kerang lumpur dibandingkan dengan wanita yang tidak mengkonsumsi kerang lumpur. Spesies $A$. edentula dimanfaatkan sebagai sumber protein hewani dengan komposisi kandungan gizi yang terdiri atas kadar air $80 \%$, protein $10,8 \%$, lemak $1,6 \%$, abu $0,75 \%$ dan karbohidrat $0,6 \%$ (Natan, 2008). Di daerah Kabupaten Muna komposisi kandungan gizi yang terdiri atas protein $7,182 \%$, karbohidrat $66,887 \%$, lemak $6,820 \%$, kolesterol 10,00 mg/dl, HDL, 6,00 mg/dl, Ca 263,385 ppm, $\mathrm{Cu} 9,107$ ppm, Mg 28,467 ppm, Fe 1,859 ppm, dan LDL serta Zn konsentrasi tidak terdeteksi (Sjafaraenan, 2011).

Di Indonesia, kerang ini kurang dikenal dan baru pertama kali diperkenalkan dalam publikasi ilmiah oleh Natan dengan nama kerang lumpur (Natan, 2008). Di Kabupaten Muna, masyarakat lokal menyebutnya ghiwo dan ditemukan melimpah di perairan estuaria, Bonea, Kepulauan Tobea dan Lambiku, Kecamatan Napabalano.

\subsection{Tujuan Penelitian}

Penelitian terhadap spesies A. edentula Linneaus, 1758 dilaksanakan dengan tujuan untuk melakukan analisis terhadap :

1. Pertumbuhan populasi kerang lumpur di daerah Kepulauan Tobea.

2. Pertumbuhan populasi kerang lumpur di daerah Lambiku.

\subsection{Kegunaan Penelitian}

Penelitian terhadap spesies A. edentula Linneaus, 1758 diharapkan dapat memberikan informasi mengenai :

1. Pertumbuhan populasi kerang lumpur di daerah Kepulauan Tobea.

2. Pertumbuhan populasi kerang lumpur di daerah Lambiku.

\section{METODOLOGI PENELITIAN}

\subsection{Tempat dan Waktu}

Penelitian dilakukan di dua daerah yang berbeda yakni di daerah Kepulauan Tobea, dan daerah Lambiku, Kecamatan Napabalano, Kabupaten Muna. Pengambilan sampel dilaksanakan pada bulan Maret sampai Mei 2011 (Gambar 1). Pengukuran panjang cangkang, lebar cangkang dan tebal cangkang dilakukan di Laboratorium Budidaya Perairan, Sekolah Tinggi Ilmu Pertanian Wuna, Raha.

\subsection{Bahan dan Alat}

Peralatan yang digunakan adalah ember untuk menyimpan sampel spesies, timbangan elektrik dengan ketelitian 0,01 g untuk mengukur bobot tubuh (cangkang dan viscera). Kaliper dengan ketelitian $0,01 \mathrm{~mm}$ untuk mengukur panjang cangkang $(\mathrm{mm})$, lebar cangkang $(\mathrm{mm})$ dan tebal cangkang $(\mathrm{mm})$.

\subsection{Prosedur Penelitian}

Kerang yang ditemukan dimasukan dalam wadah berupa ember plastik dan ditambahkan air laut dan lumpur agar kerang tetap terendam, kemudian dibawa ke laboratorium untuk dilakukan pengukuran.

Pengamatan dilakukan sebulan sekali terhadap contoh kerang lumpur yang diambil secara acak. Jumlah contoh sampel bervariasi, bergantung pada banyak kerang yang ditemukan saat pengambilan.

$$
\text { Pengukuran panjang cangkang }
$$

dilakukan dengan menggunakan kaliper dengan ketelitian $0,01 \mathrm{~mm}$. Panjang 


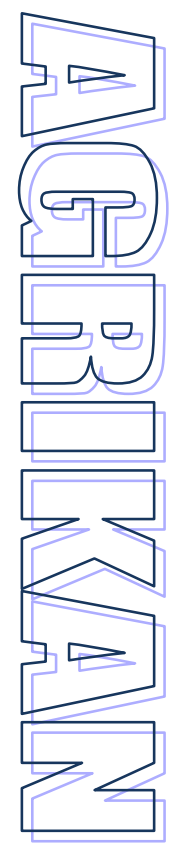

cangkang adalah jarak dari ujung anterior ke ujung posterior cangkang. Lebar cangkang adalah jarak yang diukur pada bagian dorsal ke bagian ventral cangkang. Tebal cangkang adalah jarak yang diukur dari tepi cangkang pada bagian atas ke tepi cangkang pada bagian bawah (Gambar 2).

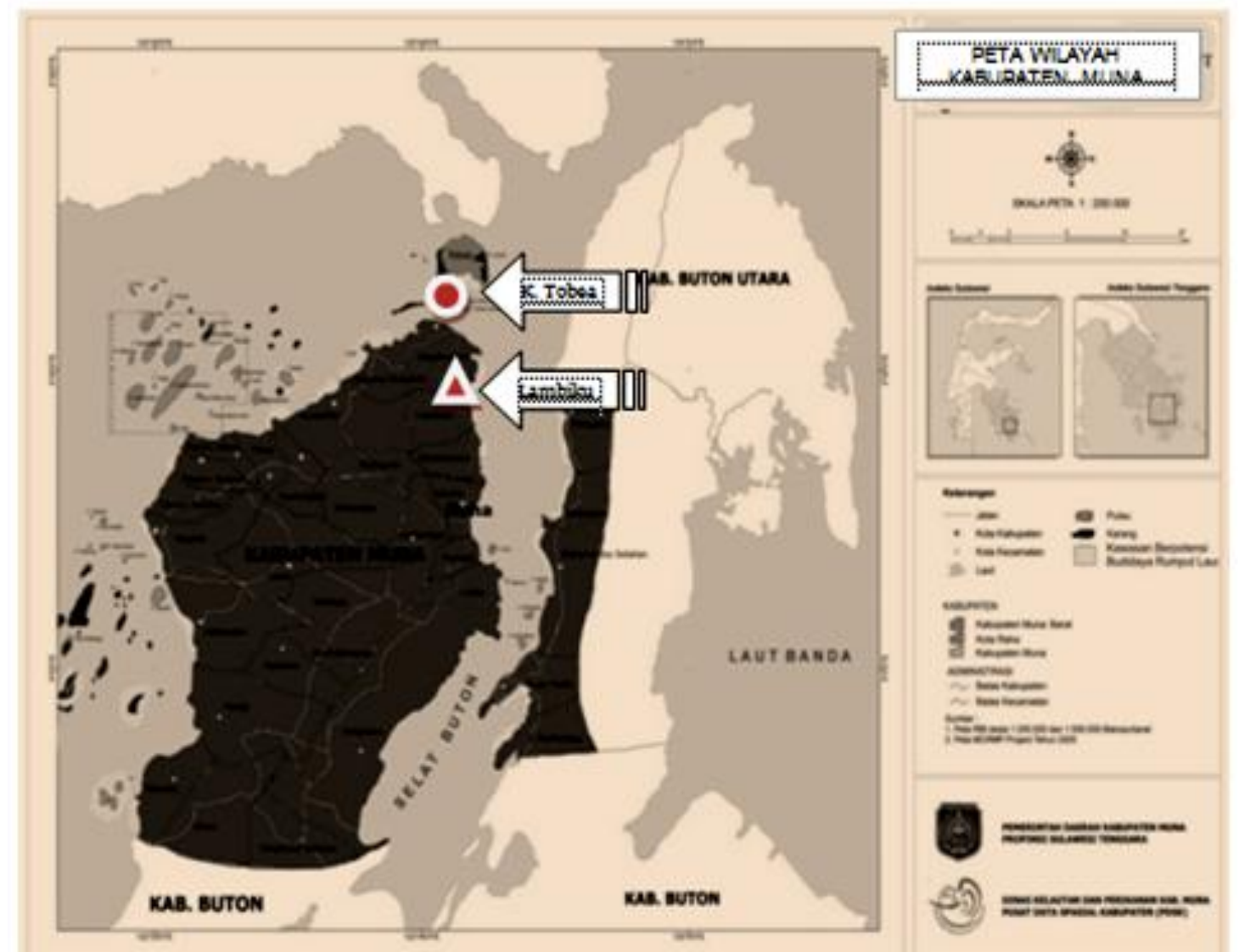

Gambar 1. Lokasi pengambilan contoh kerang di daerah Kepulauan Tobea dan di daerah Lambiku, pesisir Kecamatan Napabalano, Kabupaten Muna

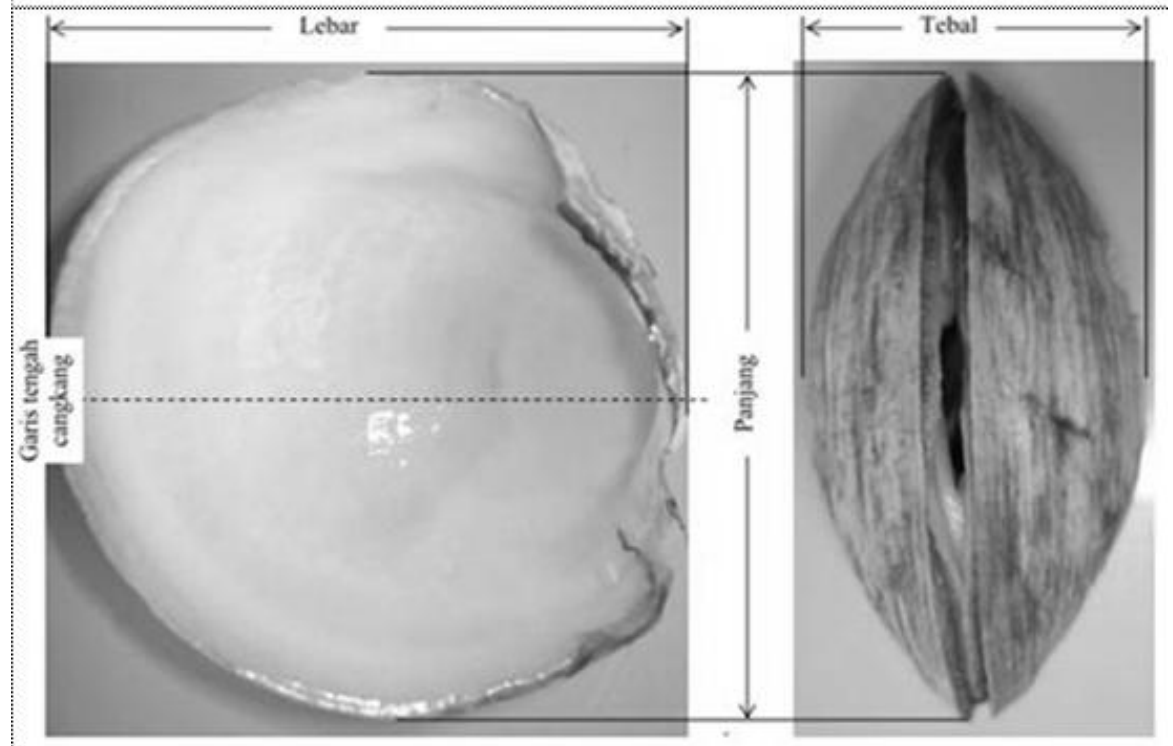

Gambar 2. Pengukuran panjang cangkang (mm), lebar cangkang (mm) dan tebal cangkang $(\mathrm{mm})$ kerang lumpur A. edentula Linnaeus, 1758. 


\subsection{Analisis Data}

Untuk mengetahui banyaknya kelompok umur (kohort) kerang lumpur, maka dianalisis dengan menggunakan Model Class Progression Analysis (MPA) dalam Software FiSAT II. Metode ini digunakan untuk menduga pertumbuhan dari populasi melalui pergeseran modus dari serangkaian data frekuensi panjang. Alasan mendasar penggunaan software FISAT II adalah oleh karena software ini memiliki kelebihan dalam hal tidak mensyaratkan adanya jumlah kohort dalam analisa data sebaran ukuran panjang (Gayanilo et al., 2005).

Analisa yang digunakan dalam penelitian ini menggunakan metode Bhattacharya yang merupakan salah satu model grafis untuk memisahkan data sebaran frekuensi panjang ke dalam beberapa distribusi normal. Berdasarkan Sparre dan Venema (1999), penentuan distribusi normal dimulai dari sisi kiri distribusi total kemudian bergerak ke sisi kanan selama masih ada distribusi normal yang dapat dipisahkan dari distribusi total.

Seluruh proses pemisahan distribusi normal menggunakan persamaan sebagai berikut :

$$
F c(x)=\frac{(n)(d L)}{(s)(\sqrt{2 \pi}} \exp \frac{(x-\bar{x})^{2}}{\left(2 S^{2}\right)}
$$

Dimana Fc (x) merupakan frekuensi teoritis, $\mathrm{N}$ merupakan jumlah pengamatan, $\mathrm{dL}$ merupakan interval kelas, $\mathrm{x}$ merupakan tengah kelas, $\overline{\mathrm{x}}$ merupakan rataan panjang, dengan harga $\pi$ sebesar 3,1459, dan $S$ merupakan simpangan baku, dengan;

$$
S=\frac{1}{n-1} \sum F i(x i-\bar{x})^{2}
$$

Dimana $\mathrm{n}$ merupakan jumlah kerang, $\mathrm{xi}$ merupakan panjang kerang $\mathrm{ke}-\mathrm{i}$ dan $\mathrm{f}$ merupakan frekuensi kerang ke $-\mathrm{i}$.

\section{HASIL DAN PEMBAHASAN}

Analisa sebaran ukuran frekuensi panjang yang diperoleh selama penelitian di dua lokasi penelitian ditemukan jumlah kohort yang relatif bervariasi, yakni di daerah Kepulauan Tobea diperoleh dua kohort, sebaliknya di daerah Lambiku diperoleh dua kohort dengan salah satu kohort memiliki frekuensi yang relatif kecil (Gambar 11a). Pengukuran pertumbuhan populasi mengikuti pergerakan frekuensi berbasis ukuran panjang cangkang yang diukur selama penelitian pada masing-masing lokasi. Interpretasi terhadap sebaran data ukuran panjang mengindikasikan terjadinya pertumbuhan pada tiap kohort kerang lumpur (Bengen et al. 1992).

Kerang lumpur memiliki cangkang yang cenderung tipis dan rapuh, menyebabkan pertumbuhan cangkang cenderung cepat. Terdapatnya ukuran kohort yang kecil diduga disebabkan oleh tekanan intensif dari kerang yang memiliki kelompok umur yang berukuran besar. Oleh karena kerang lumpur memiliki persebaran yang mengelompok. Hal ini terjadi karena adanya kompetisi dalam memperoleh makanan dan tempat dalam satu kelompok. Sebagaimana yang dilaporkan oleh Latale (2003) dan Natan (2008) menunjukkan hal yang sama, yakni pada setiap bulan pengamatan terdapat kohort dalam sebaran frekuensi ukuran yang kecil.

Dugaan lainnya adalah adanya tekanan eksploitasi sehingga mengakibatkan terjadinya perubahan frekuensi kelompok ukuran. Sebagaimana dilaporkan Rice et al. (1989) dalam Natan (2008), Bivalvia Mercenaria mercenaria di Teluk Narragansett bahwa pengaruh upaya tangkapan yang intensif mengakibatkan ukuran muda semakin kecil frekuensinya dibanding dengan bivalvia yang lebih tua.

Perhitungan panjang infinity $\left(\mathrm{L}_{\infty}\right)$ memperlihatkan besaran ukuran panjang cangkang yang bisa dicapai oleh individu kerang lumpur. Koefisien pertumbuhan (K) memberikan informasi mengenai laju pertumbuhan kerang dan merupakan salah satu faktor penting untuk mencapai ukuran panjang infinity. Harga K berbeda antara satu spesies dengan spesies lainnya, bahkan perbedaan ini dapat terjadi pada spesies yang sama dalam lokasi yang sama pula. Harga koefisien pertumbuhan K menunjukkan kecepatan suatu spesies mencapai ukuran panjang atau berat infinity (Sparre dan Venema, 1998).

Berdasarkan analisa parameter pertumbuhan populasi, untuk daerah Kepulauan Tobea diperoleh nilai koefisien pertumbuhan panjang cangkang infinity $\left(\mathrm{L}_{\infty}\right)$ sebesar $65,6 \mathrm{~mm}$ dengan koefisien pertumbuhan $(\mathrm{K})$ sebesar 1,18 per tahun. Untuk daerah Lambiku diperoleh nilai koefisien pertumbuhan panjang cangkang infinity $\left(\mathrm{L}_{\infty}\right)$ sebesar 73,75 $\mathrm{mm}$ dengan koefisien pertumbuhan $(\mathrm{K})$ sebesar 0,73 per tahun. 
Panjang cangkang infinity $\left(\mathrm{L}_{\infty}\right)$ kerang yang sama sebagaimana yang dilaporkan oleh Lebata (2000 dan 2001) di Philipina yakni sebesar 136,7 mm, sedangkan yang dilaporkan oleh Natan (2008) di daerah Teluk Ambon Bagian Dalam yakni sebesar $70,58 \mathrm{~mm}$. Jika dibandingkan dengan panjang cangkang infinity kerang lumpur di Kepulauan Tobea sebesar 65,6 $\mathrm{mm}$, maka kerang lumpur di daerah Kepulauan
Tobea relatif lebih kecil dari apa yang telah dilaporkan. Panjang cangkang infinity antara daerah Kepulauan Tobea sebesar 65,6 $\mathrm{mm}$ dengan koefisien pertumbuhan sebesar 1,18 pertahun relatif lebih kecil dibandingkan dengan panjang cangkang infinity pada daerah Lambiku sebesar 73,75 mm dengan koefisien pertumbuhan sebesar 0,73 pertahun (Tabel 1).

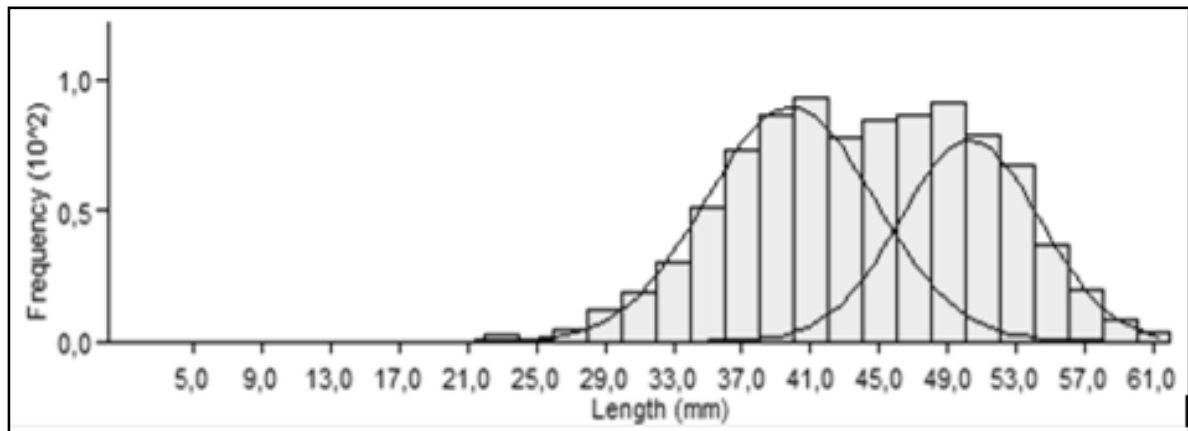

(a)
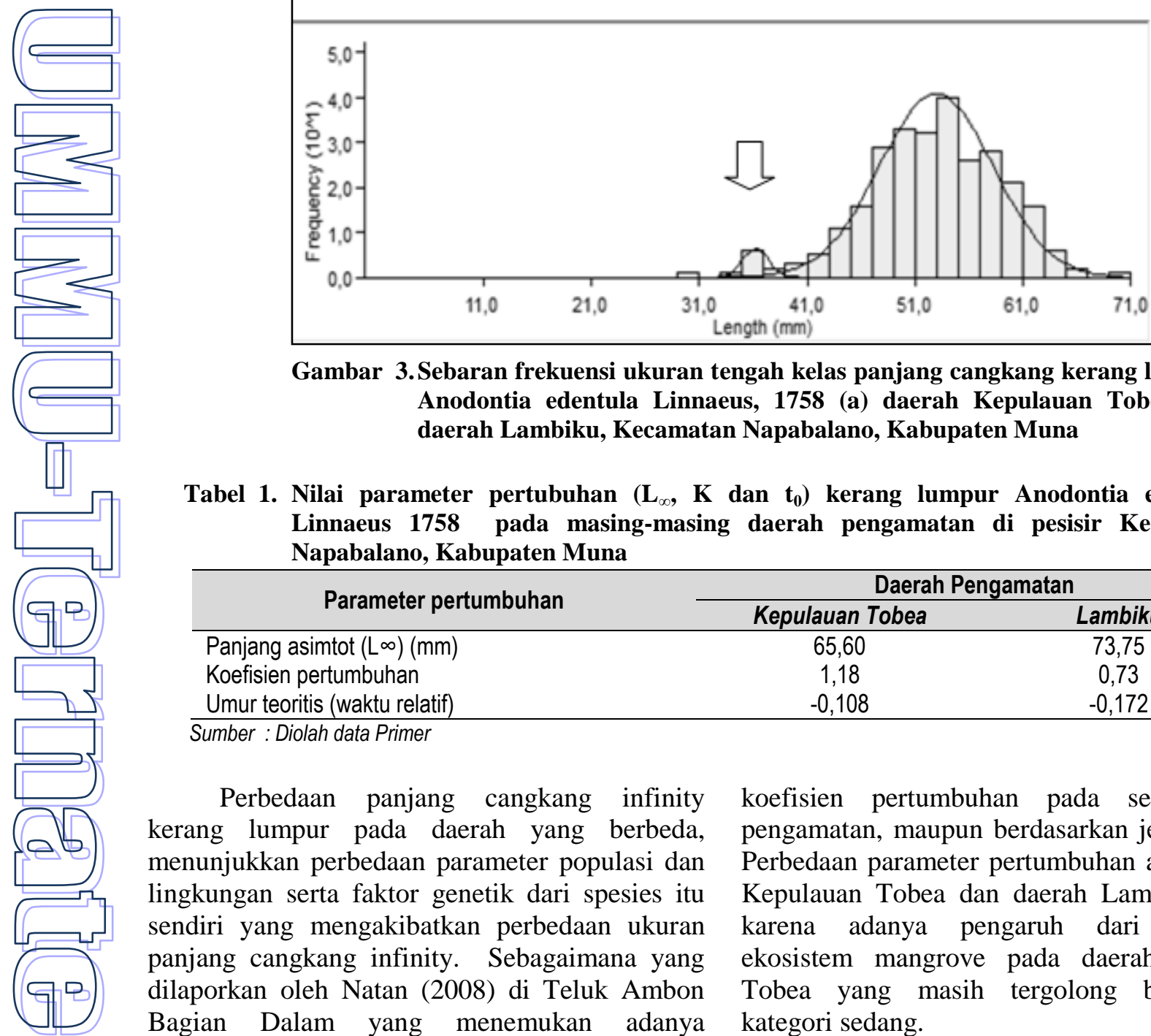

Gambar 3. Sebaran frekuensi ukuran tengah kelas panjang cangkang kerang lumpur Anodontia edentula Linnaeus, 1758 (a) daerah Kepulauan Tobea, (b) daerah Lambiku, Kecamatan Napabalano, Kabupaten Muna

Tabel 1. Nilai parameter pertubuhan $\left(L_{\infty}, K\right.$ dan $\left.t_{0}\right)$ kerang lumpur Anodontia edentula, Linnaeus 1758 pada masing-masing daerah pengamatan di pesisir Kecamatan Napabalano, Kabupaten Muna

\begin{tabular}{lcc}
\hline \multirow{2}{*}{ Parameter pertumbuhan } & \multicolumn{2}{c}{ Daerah Pengamatan } \\
\cline { 2 - 3 } & Kepulauan Tobea & Lambiku \\
\hline Panjang asimtot $(\mathrm{L} \infty)(\mathrm{mm})$ & 65,60 & 73,75 \\
Koefisien pertumbuhan & 1,18 & 0,73 \\
Umur teoritis (waktu relatif) & $-0,108$ & $-0,172$ \\
\hline
\end{tabular}

Sumber : Diolah data Primer

Perbedaan panjang cangkang infinity kerang lumpur pada daerah yang berbeda, menunjukkan perbedaan parameter populasi dan lingkungan serta faktor genetik dari spesies itu sendiri yang mengakibatkan perbedaan ukuran panjang cangkang infinity. Sebagaimana yang dilaporkan oleh Natan (2008) di Teluk Ambon Bagian Dalam yang menemukan adanya perbedaan panjang cangkang infinity dan koefisien pertumbuhan pada setiap stasiun pengamatan, maupun berdasarkan jenis kelamin. Perbedaan parameter pertumbuhan antara daerah Kepulauan Tobea dan daerah Lambiku, diduga karena adanya pengaruh dari lingkungan ekosistem mangrove pada daerah Kepulauan Tobea yang masih tergolong baik dengan kategori sedang. 
Selain parameter lingkungan, komposisi substrat diduga turut menentukan pertumbuhan kerang lumpur. Pada daerah Kepulauan Tobea, komposisi substrat dengan persentase kandungan pasir yang tergolong lebih banyak dibandingkan dengan daerah Lambiku. Hal ini terjadi karena di Kepulauan Tobea tidak mendapatkan pengaruhpengaruh daratan. Sedang di daerah Lambiku, pengaruh daratan relatif lebih dominan. Sehingga selain kandungan bahan organik, perbedaan lokasi dengan karakteristik ekosistem mangrove turut menentukan pertumbuhan kerang lumpur.

Berdasarkan panjang cangkang infinity $\left(\mathrm{L}_{\infty}\right)$ dan koefisien pertumbuhan $(\mathrm{K})$, maka dapat dilakukan estimasi panjang pada saat umur sama dengan nol (0) $\left(\mathrm{t}_{0}\right)$ dengan menggunakan formula yang dikembangkan oleh Pauly (1980), yakni :

$\log _{10}\left(-t_{0}\right)=-0,3922-0,2752 \log _{10} L_{\infty}-$ $1,038 \log _{10} \mathrm{~K}$.

Sparre dan Venema (1998) menyatakan umur $\mathrm{t}_{0}$ dinamakan sebagai parameter kondisi awal (the initial condition parameter) yang menentukan titik dalam ukuran waktu relatif ketika memiliki panjang nol. Perhitungan dengan menggunakan formula Pauly (1980), diperoleh nilai $\mathrm{t}_{0}$ kerang di Kepulauan Tobea sebesar 0,108 tahun atau 1,00 bulan, untuk Lambiku sebesar -0,172 tahun atau 1,00 bulan (Tabel 3). Hasil perhitungan dengan menggunakan rumus von Bertanlanffy didapatkan persamaan pertumbuhan sebagai berikut.

Kep. Tobea $\quad \mathrm{L}(\mathrm{t})=65,6^{*}\left[1-\mathrm{e}^{(-1,18(\mathrm{t}+0.108)}\right]$. Lambiku $\quad \mathrm{L}(\mathrm{t})=73,75^{*}\left[1-\mathrm{e}^{(-0,73(\mathrm{t}+0.172)}\right]$.

Berdasarkan beberapa parameter pertumbuhan (Tabel 3), dapat ditentukan rentang hidup (longevity) kerang lumpur pada daerah Kepulauan Tobea maupun pada daerah Lambiku. Berdasarkan persamaan von Bertanlanffy $\mathrm{t}=$ $\log 10\left(1-\mathrm{Lt} / \mathrm{L}_{\infty} / \mathrm{K}+\mathrm{t}_{0}\right)$ maka didapatkan umur maksimum $\mathrm{t}_{\text {maks }}$ masing-masing sebesar 4,5 tahun dan 3,5 tahun untuk daerah Kepulauan Tobea dan daerah Lambiku. Dengan memperhatikan $\mathrm{t}_{\text {maks }}, \mathrm{t}_{0}, \mathrm{~L}_{\infty}$ dan $\mathrm{K}$ maka dapat dibentuk kurva dugaan pertumbuhan kerang lumpur dari model yang dibentuk pada daerah Kepulauan Tobea (Gambar 4a) dan pada daerah Lambiku (Gambar 4b).
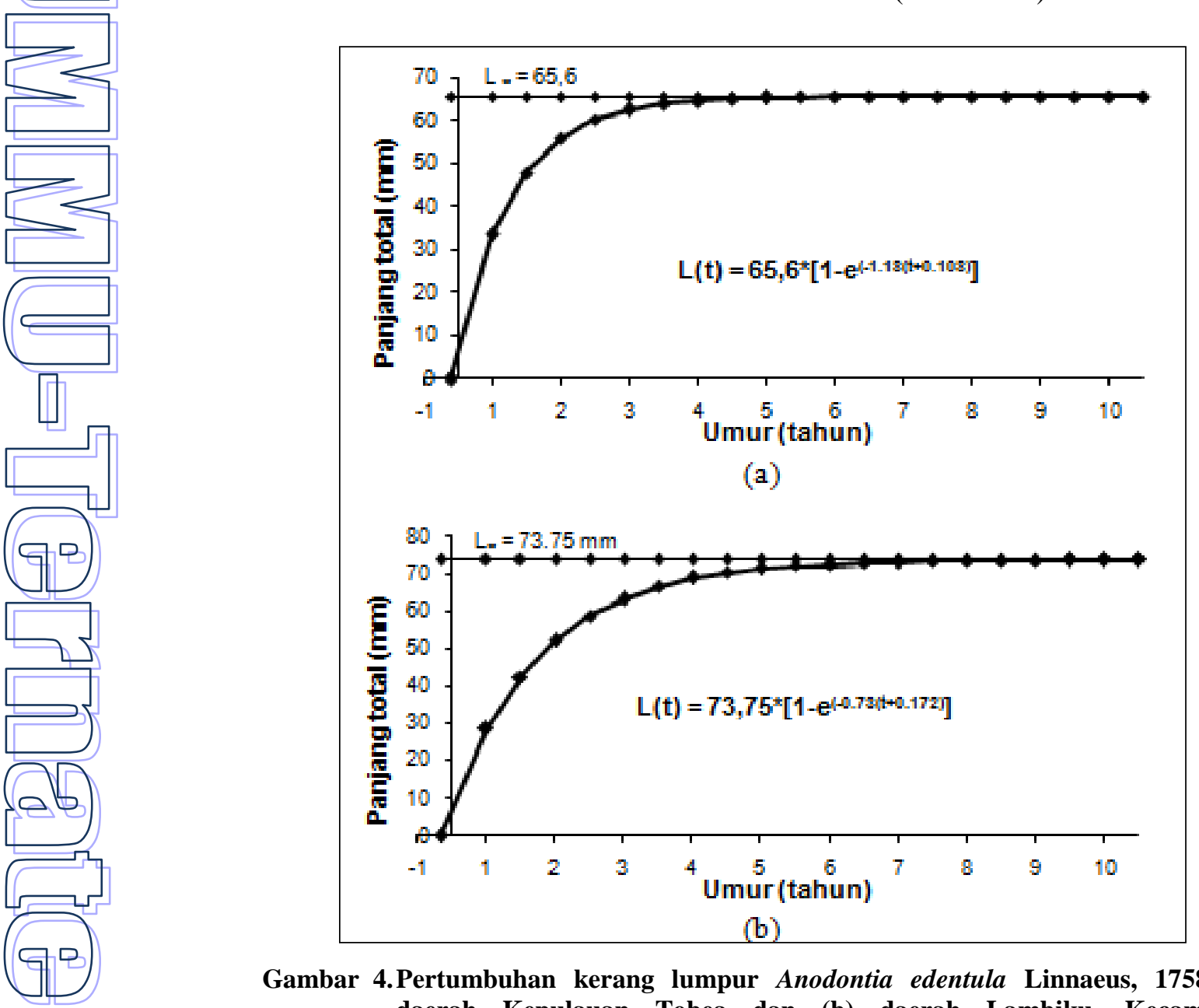

Gambar 4.Pertumbuhan kerang lumpur Anodontia edentula Linnaeus, 1758 (a) daerah Kepulauan Tobea dan (b) daerah Lambiku, Kecamatan Napabalano, Kabupaten Muna 


\section{KESIMPULAN}

Berdasarkan hasil dan pembahasan yang dilakukan, maka dapat disimpulkan beberapa hal sebagai berikut.

a. Pertumbuhan populasi di daerah Kepulauan Tobea lebih kecil dibandingkan dengan daerah Lambiku. b. Panjang infinity pada daerah Kepulauan Tobea lebih kecil dibanding pada daerah Lambiku dengan koefisien pertumbuhan masing-masing sebesar 1,108 dan 0,73 per tahun.

\section{DAFTAR PUSTAKA}

Bengen, D.G., P. Lim and A. Belaud. 1992. Fish Population structure and typology in there ancient arm of the Gronne river. Annls Limnol. 28 (1): 25-36

Cosel, R.V. 2006. Taxonomy of tropical West African bivalves. VI. Remarks on Lucinidae (Mollusca, Bivalvia), with description of six new genera and eight new species. Zoosystema 28 (4) : 805-851.

Effendie, M.I. 1997. Biologi Perikanan. Yayasan Pustaka Utama. Yogyakarta. 163p.

Gayanilo, F.C. Jr., P. Sparre. And D. Pauly. 2005. FAO-ICLARM Stock Assessment Tools II (Fisat II), Revised version, User's guide. FAO Computerized Information Series (Fisheries). No. 8, Revised version, Rome, FAO. 168p.

Latale, S.S. 2003. Studi Pendahuluan Ekplorasi Sumberdaya Anodontia edentula Pada Perairan Pantai Desa Passo Teluk Ambon Bagian Dalam. Skripsi. Fakultas Perikanan Universitas Pattimura. Ambon. 58 hal.

Lebata, M.J.H.L. 2000. Elemental sulfur in the gills of the mangrove mud clam Anodontia edentula (Family Lucinidae). Journal of Shellfish Research 19(1): 241-245.

Lebata, M.J.H.L. 2001. Oxygen, sulphide and nutrient uptake of the mangrove mud clam Anodontia edentula (Family : Lucinidae). Marine Pollution Bulletin 11(42): 1133-1138.

Lebata, M.J.H.L. and J.H. Primavera. 2001. Gill structure, anatomy and habitat of Anodontia edentula; evidence of endosybiosis. Journal of Shellfish Research, 20(3): 1273 - 1278.

Natan, Y. 2008. Studi Ekologi dan Reproduksi Populasi Kerang Lumpur Anodontia edentula Pada Ekosistem Mangrove Teluk Ambon Bagian Dalam. Disertasi. Program Studi Ilmu dan Teknologi Kelautan. Institut Pertanian Bogor. Bogor. 179 hal.

Poutiers, J.M. 1998. Bivalves (Acephala, Lamellibranchia, Pelecypoda), pp 123-362. In Carpenter, K.E and V.H. Niem. 1998. FAO Species Identification Guide for Fishery Purposes. The Living Marine Resources of The Western Central Pacific 1. Seaweeds, Corals, Bivalves and Gastropods. Rome. 686p.

Razak, A. 2002. Dinamika Karakteristik Fisika-Kimia Sedimen dan Hubungannya Dengan Struktur Komunitas Moluska Benthik di Muara Bandar Bakali Padang. Thesis. Program Pascasarja, Institut Pertanian Bogor. Bogor.

Sugiyono. 2006. Statistika Untuk Penelitian. Penerbit Alfabeta. Bandung.

Sjafaraenan. 2011. Pengaruh Konsumsi Daging Kerang Semele sp. Terhadap Kadar Estradiol Pada Wanita Perimenopause. Disertasi. Program Pascasarjana, Universitas Hasanuddin. Makasaar. Sparre, P. dan S.C. Venema. 1999. Introduksi Pengkajian Stok Ikan Tropis. Buku I. Manual. Pusat Penelitian dan Pengembangan Perikanan. Jakarta. 438p.

Taylor, J.D. and E.A. Glover. 2000. Functional anatomy, chemosymbiosis and evolution of the Lucinidae. Geological Society, London, Special Publications; 2000; v. 177; p. 207-225; http://sp.lyellcollection.org/cgi/content/abstract/177/1/207].

Taylor, J.D. and E.A. Glover., 2004. Systematic revision of Australian and Indo-Pacific Lucinidae (Mollusca: Bivalvia): Pillucina, Wallucina and descriptions of two new genera and four new species. Records of the Australian Museum 53(3): 263-292.

Taylor, J.D. dan E.A. Glover., 2007. Diversity of chemosymbiotic bivalves on coral reefs: Lucinidae (Mollusca, Bivalvia) of New Caledonia and Lifou. Zoosystema 29 (1) : 109-181. 